\title{
A Review of Taylor Mac's 24-Decade History of Popular Music Marathon
}

\section{Cover Page Footnote}

Thank you to Teddy Wolff for the photos, to Cullan Riley and Christine Riley for their support and memories and of course, to my dear friend, the incomparable Taylor Mac. 
Performance Review of Taylor Mac's A 24-Decade History of Popular Music Marathon St. Ann's Warehouse, Brooklyn, NY

October 8 through 9, 2016

Co-Directors: Niegel Smith and Taylor Mac

Musical Arranger/Director: Matt Ray

Costume Designer: Machine Dazzle

Scenic Designer: Mimi Lien

Photos received with permission from the photographer and Pomegranate Arts.

Since 2011, queer performer Taylor Mac (who prefers the gender pronoun "judy" in performance, but uses male gender pronouns day-to-day, so I use "Mac" or "he/his" hereafter) has traveled around the United States and beyond, training marathon-like for $A$ 24-Decade History of Popular Music. This preparation culminated on October 8-9, 2016, when Mac and his supporting cast of dozens completed the staggering feat of performing for 24 hours straight (I acknowledge the irony here). The concert pulled liberally from the American songbook, using popular music from 1776 to 2016 as an attempt to collectively exorcise the specters of the patriarchy and exonerate the oppressed in what Mac deems a "radical faerie ritual." Since 1979, these radical faeries continue to enact a counter cultural movement, celebrating creative community and spirituality through antiassimilationist gatherings toward gender fluidity and queer celebration. Mac saw the faeries as inspiration for how to build a large-scale event that disrupted the historical narrative of sex, gender, race and ethnicity in America as well as providing a space to collectively process trauma drummed up by our country's fraught past.

I was particularly struck by Mac's spellbinding manipulation of temporality to enchant a captive audience of 650 for a full day and night. Herein I apply Jacques Derrida's notion of "l'avenir," to demonstrate how Mac performatively queered time by breaking down the veil between the past and the present while embodying the role of what the French theorist deemed the "unexpected visitor." This unexpected visitor appeared in many unpredictable forms throughout the performance. Derrida notes that l'avenir annunciates the arrival of the "Other," and in Mac's case attempts to employ a reorientation of the normative American past as harbinger for a queerer and more hopeful American future. Mac broadly defines queer as that which stands opposite to perfection, 
and this became the mantra for a day of creativity toward political agency. Throughout the performance, Mac reveled in an unexpected resurrection of the historic, refashioning it, in part, through the elevation of the taboo, the base, the hedonistic and the underrepresented.

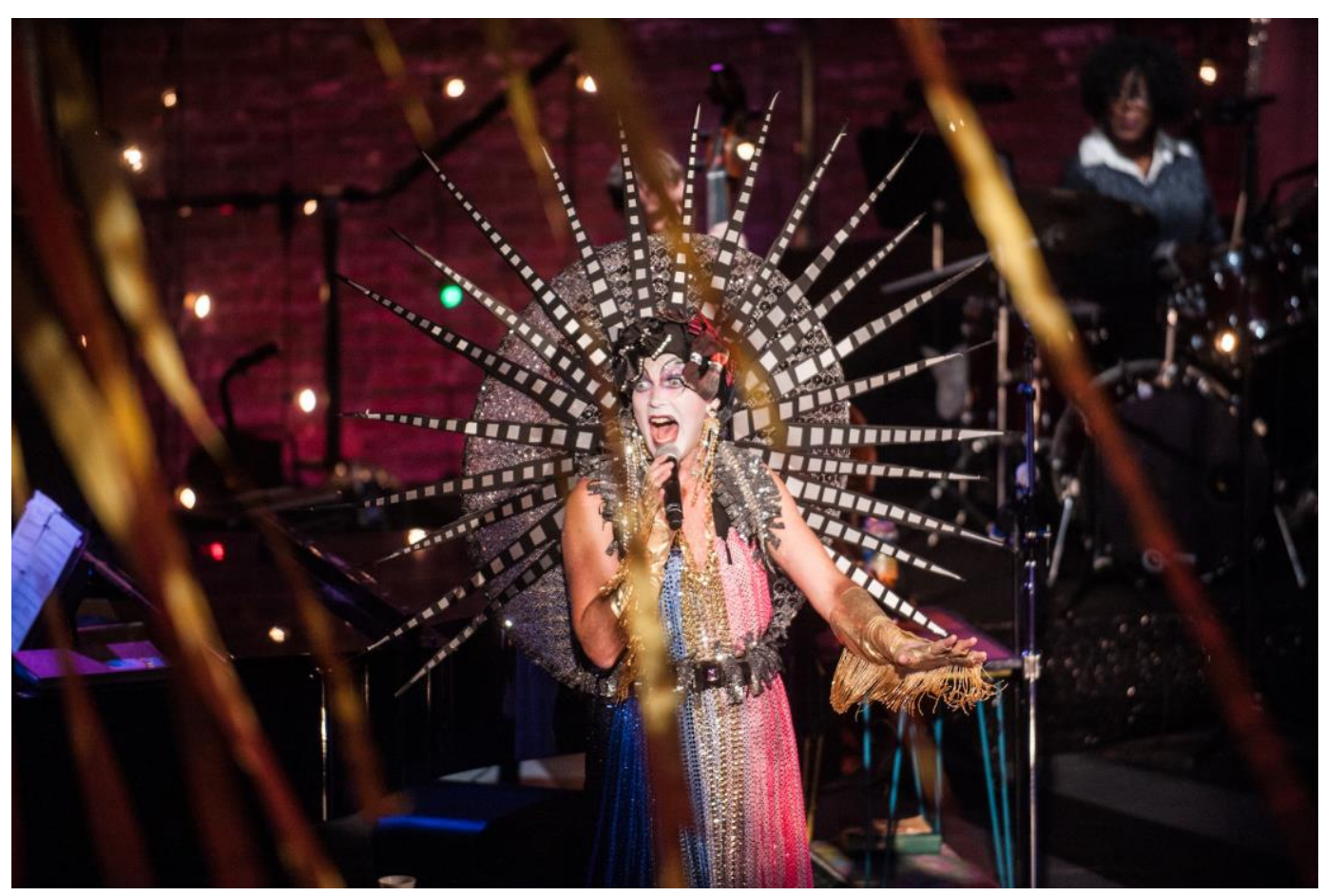

Photo by Teddy Wolff

Perhaps the first place that l'avenir reared its head was in the unique selection of 246 songs that Mac and musical director/arranger Matt Ray took over five years in carefully selecting. Some of the songs, like Mac's sing-along version of Yankee Doodle as segue to Federalism in Act I (1776-1806), were intentionally selected to represent the kind of nationalism drawn from the patriarchal history of most textbooks, placed, in part, to remind us of the dangers of nostalgia. These were queerly contrasted, however, by random and unexpected choices, like a series of once popular period drinking songs in the third hour that stood in counterpoint to the blind patriotism typically associated with Yankee Doodle. In selecting such songs and impersonating a drunk, loose and scantily clad character deemed “Crazy Jane," Mac embodied a voice deemed too disreputable for the archive, breaking down barriers of gender, class and conservative morality. These are queer notions that are never found in traditional high school history classes, where most 
Americans are first exposed to this knowledge. This was one of the first examples of Mac's attempt to resurrect the voices of the marginalized and the silenced. Mac's selections throughout the performance were pointed, specific and by no means comprehensive. While some of my colleagues who also attended the concert found this approach to history random and even haphazard, I argue that the careful selection perfectly expresses a queer take on Derrida's unexpected visitor, which grounds itself in that which is unknown, unpredictable and unforeseeable. It also demonstrated the notion of queerness as imperfect, unexpected and even messy.

Our path through American history was signposted by the twenty-four intricate and outré costumes, which required the assistance of designer Machine Dazzle to change in and out of as the clock struck each passing hour. While each costume took its inspiration from the particular decade it represented - an $18^{\text {th }}$ century sequined Macaroni for the Revolution, a hoop-skirted Southern Belle for the decade leading to the Civil War, an art-deco/Expressionist flapper fantasia for the 1920s, and a Robert Mapplethorpe inspired leather fetish/glam rock ensemble for the 1970-the styles were both hyperbolized and intellectual. Dazzle, who also appeared in a new complimentary ensemble with each transition (my favorite involved a 1970s S\&M ensemble with requisite dog tail-shaped butt plug in Act VII's “A Backroom Sex Party”), was clearly building on the genderfuck aesthetic that has been a staple of Mac's work for over fifteen years. This was also a nod to Mac's gay liberation-era forebears like The Cockettes, Jack Smith and the founders of the Ridiculous Theatre (John Vaccaro, Ronald Tavel and Charles Ludlam) who set the cornerstones for this very kind of aesthetic and performance. This particular convention resonates with Derrida's notion of looping time, where things experienced in the present will only begin to make sense in a future context that reflects back on the past, all the while separated by the spirit of unexpectedness embodied through the concept of l'avenir. So although the costumes may have resonated with many audience members who were aware of the queer traditions from which Mac and Dazzle were pulling, it was not until the twentieth hour that Mac explicitly mentioned Tavel and Vacarro by name. Throughout the performance the costumes took on their own mode of performativity and the surprise that they provided each hour created a through-line of expectation and record, as the costumes continued to be 
displayed in a lobby tableau after they had been worn and discarded. Additionally, as time became harder to keep track of as the hours wore on without respite, the costumes worked as metaphoric numerals on the symbolic clock in which we found ourselves. Another example of looping time occurred during the 1960s: dressed as a kind of Warholian Jackie O. (and topped off with the iconic pink pillbox hat), Mac used the current Flint Water crisis as a lens with which to honor and resurrect the link between Motown and Civil Rights. This segment highlighted how little stakes have changed over the past fifty years in America and as an appendix Mac invited the audience to write directly to Michigan governor Rick Snyder, providing his contact information.

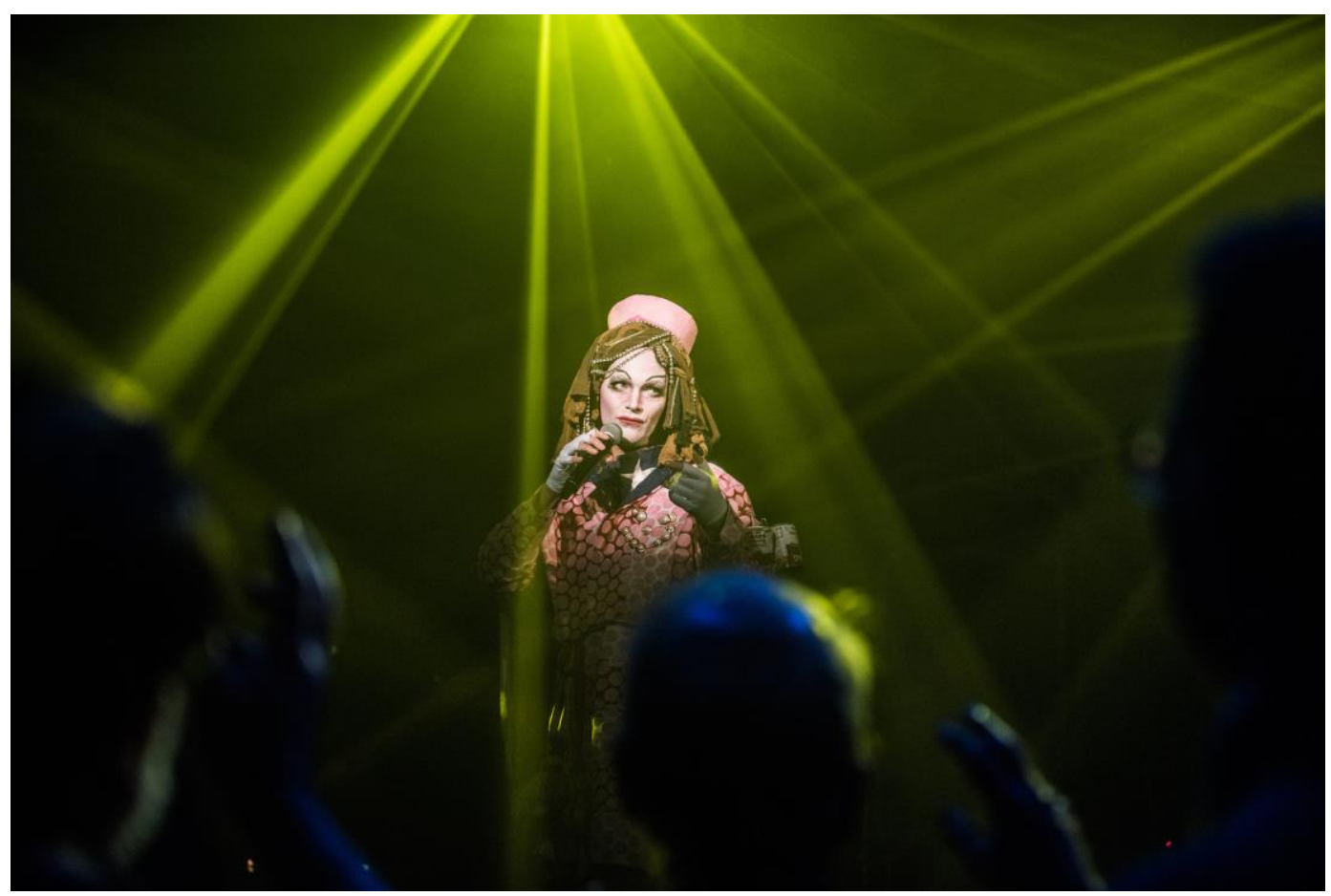

Photo by Teddy Wolff

Mac unexpectedly manipulated the historical narrative through what I refer to as an arch dramaturgy — or a queer approach to both process and product — in collaboration with co-director Niegel Smith. This queering, appeared throughout, affecting the structure of the concert in a variety of forms. The first was through the retention of iconic songs by popular artists, like the second section of Act III (1836-1866) dedicated to Stephen Foster (as a symbol of the antebellum slave-holding South) and Walt Whitman (as a symbol of the abolitionist/transcendentalist North). As "father of 
American music," and "America's first poet of democracy," Foster and Whitman can hardly be considered outlanders in American cultural history, but Mac's treatment which placed the figures in a symbolic hybrid "boxing/wrestling match," demanded that the audience look beyond the moralistic binary of the soon to be formed Union and Confederacy to closer examine the quality and resonance of the Foster and Whitman's original texts. The boxing match, which also celebrated pugilism as a staple of popular entertainment in the mid-nineteenth century, was pantomimed by an audience volunteer representing Foster, Mac representing Whitman and boylesque performer Tigger Ferguson (donning a Mexican lucha libre mask and little else) as referee. Songs were paired off into "rounds" and the audience voted by throwing ping-pong balls that had been distributed by a throng of volunteer hosts deemed the "Dandy Minions." Thus, Foster and Whitman were completely reoriented through Mac's queer lens in a bit of unexpected fun and as a prime example of arch dramaturgy as reflected in performance.

The Dandy Minions, comprised of many well-known downtown queer performers from New York City, helped to maintain the spirit of l'avenir throughout by leading the audience in seemingly impromptu participatory activities as well as helping to facilitate choreographed movement throughout the cavernous space of St. Ann's. The Dandy Minions continually changed into dragged-up costumes with every Act (as opposed to Mac and Dazzle's transformation with each decade), though their costumes worked anachronistically across the concert, informed by the periods covered but seldom lining up with the decade being performed. The playbill, which only listed the thematic acts of the performance, gave little to no clues what the audience should expect, so the Dandy Minions became essential components to successful execution of a concert that continuously demanded a remaking of the playing space as well as the audience's position(s) of engagement with Mac and the other performers. Because so much of the event was dependent on risk (particularly if Mac's voice and body could make it through the exhaustive demand of a non-stop 24-hour performance) trusting the Dandy Minions was essential for the production to succeed. On a macro level the themes of risk and trust were linchpins to the narrative formed through the evening's songs. Whether concerning the Underground Railroad, proto-feminist Women's Lib, secret gay love, or the HIV/AIDS crisis, these concepts were essential for our ancestors and predecessors who 
faced oppression to gather, survive and fight for the benefits of equality we have today. Mac, who went into the 24-hour performance having only performed for 12 hours continuously at Vassar College in July 2016, took the greatest risk of all-metaphorically sacrificing himself for the sake of his art and our collective experience.

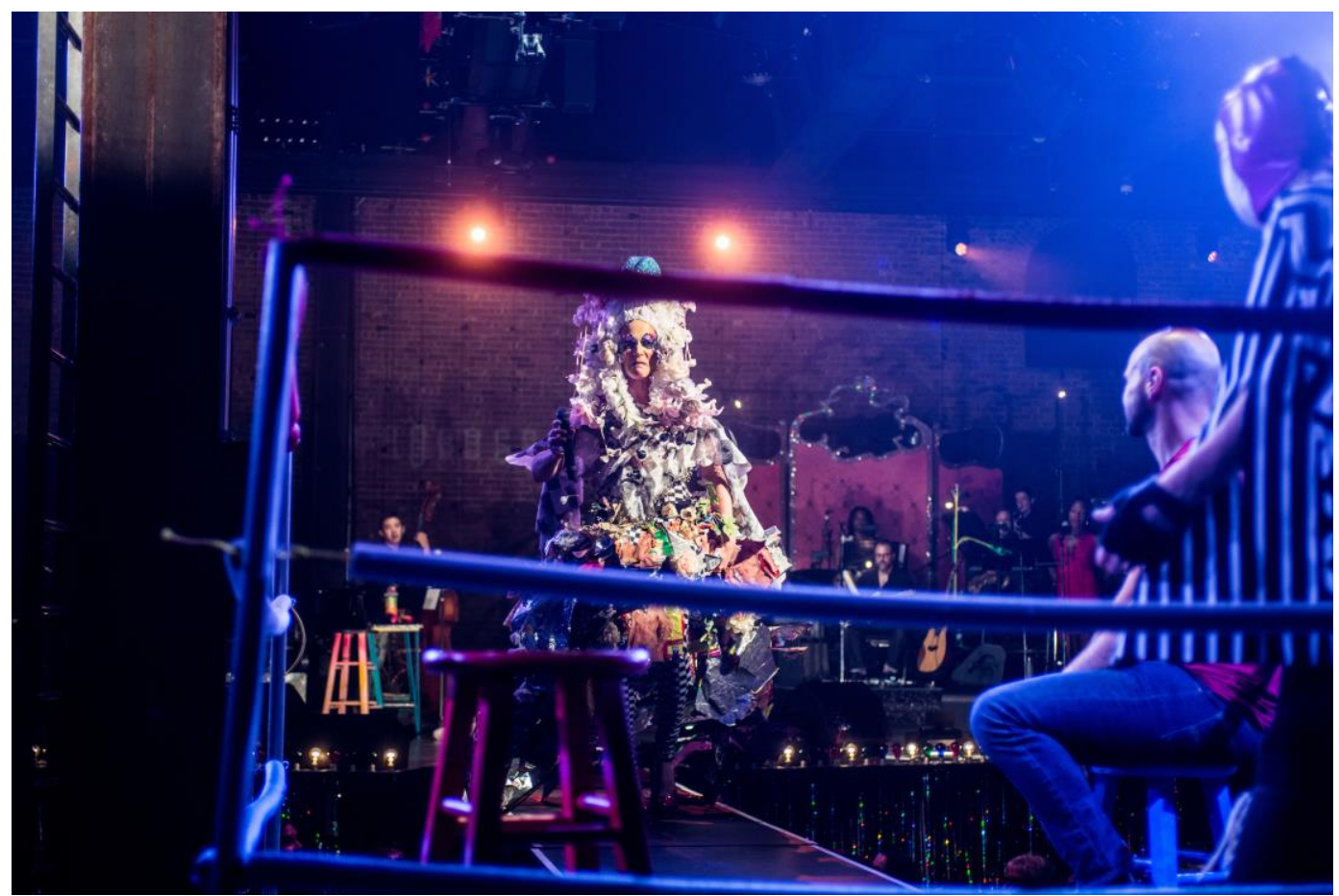

Photo by Teddy Wolff

Although the audience entered into a traditional proscenium-style set-up of chairs divided into rows and aisles, by Act II Mac directed the Dandy Minions to remove half of the chairs to prepare for the fifth hour (1816-1826) deemed "Blindfolds," which was dedicated to the invention of braille. The audience was instructed to don opaque masks, handed out by the Dandy Minions, before wandering without sight to new spaces in the venue. Aside from reminding us of the reality of those who are less-abled (and I want to stress that this by no means represented a pantomimic trying-on of challenges) this sequence represented the crucial American tradition of immigration, while reminding us of the importance of building and rebuilding community. The same technique was applied differently throughout the evening to transform the space as a visual metaphor for the history being represented, whether it involved a breaking apart or coming together. Some examples of this choreography include the remaking of the space into a "farmhouse 
dining room" during Reconstruction in hour seven, a race with pillows and mattresses to "stake claim" during an Oklahoma land rush segment in hour nine and the movement of all men between eighteen and forty to the stage to symbolize World War I in hour fourteen. Admittedly all of the movement combined with hours upon hours without sleep was daunting and often uncomfortable, but the experience resonated with the struggle and discomfort that is so often found in oppressive constructs and that is essential to make change. Although Mac remained a constant and consummate host throughout the marathon, the spirit of l'avenir was found in a variety of special guests throughout the evening including a temperance choir, a bevy of burlesque dancers, a high school marching band, and a herd of self-declared radical lesbians.

As the concert moved chronologically forward from the Revolutionary War period to 2016 Mac moved backwards in time to his roots. As Mac guided the audience through the decades, a member of the band (initially twenty-four) would part every hour, concluding in the last hour with only Mac playing the ukulele on the stage-an instrument that has become iconic for him since the genesis of his career. Performing a series of original songs penned for the concert, Mac's final pared down image and style hearkened back to early days as a downtown queer performer in New York City; a stark and dramatic contrast to the sheer spectacle of the opening and preceding hours the day before. Through this performance Mac embodied the "unexpected visitor" simultaneously moving toward both the past and the future. As the audience was pushed forward through time toward the present, at some point, Mac as "judy" discreetly began to slip back, queerly working against the tides of history as progressive, linear and only forward moving. Mac embodied the notion of the unexpected visitor at the conclusion because rather than a grand and comprehensive finale, which the concert seems dramaturgically structured to move toward, he surprised us with an act of intimacy. Plagued by exhaustion and struggling to find the strength to keep his ukulele upright, Mac relied on the collective emotion and energy of the audience to help him to the finish line. For Mac, who often associates his performance with the sacred rituals found at the center of ancient Greek theatre, this was the final sacrifice that the radical faerie ritual had been working toward for the span of the performance. 
For me, this final hour resonated with the stories around Judy Garland's infamous 1961 concert at Carnegie Hall. Described as both a revival meeting and a solo concert for every individual in attendance, Mac brilliantly towed the same line while also bringing us into the present with a touching nod to the origin of his preferred gender pronoun, "judy," in performance. Many attendees of Garland's concert recollect the uniqueness of the event where the boundaries between performer and the audience were dissolved. As James Kaplan writes, "This was something different: performer and audience supporting each other, communicating with each other, as intimates, lovers almost, in a hall of 3,000 people." While the audience for A 24-Decade History of Popular Music was twenty percent the size of Garland's, the unexpectedness of the experience resonated. Moreover the arrival of Garland's spectre at the end of the performance-Mac alone on stage, carrying the audience for a final hour-embodied the notion of l'avenir. Garland, who is often seen as a mascot for gay liberation (her funeral took place on the same day that the watershed Stonewall Riots erupted), looped us back to the origins of queer visibility. Mac had succeeded in taking us over the rainbow. Moreover, Mac had reenacted her funeral procession earlier in the evening.

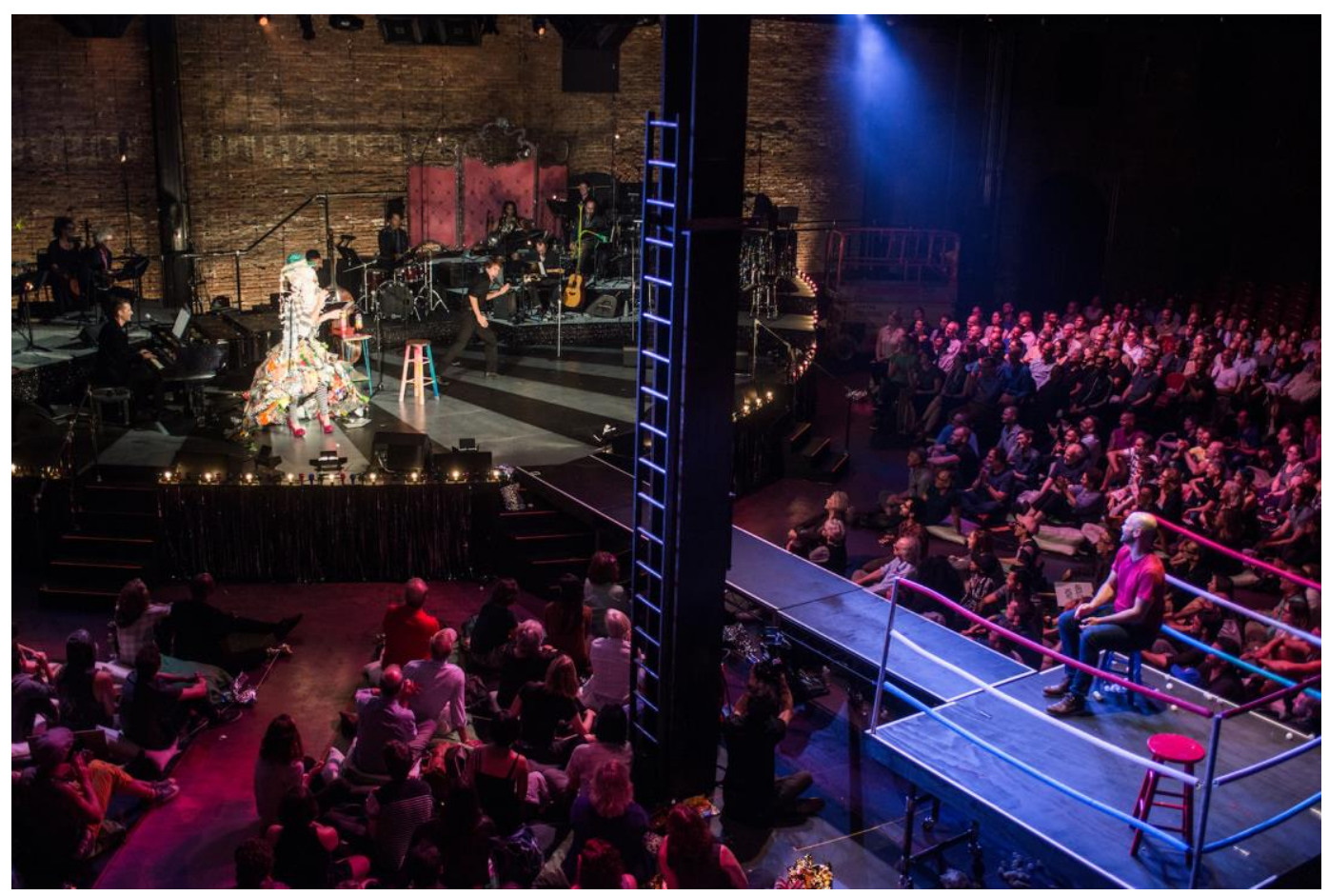

Photo by Teddy Wolff 
Anyone who attended the marathon concert can remark on the enchantment of the 24 hours we spent together. As if from a fairy-tale we emerged from the venue into a rainy afternoon with a gorgeous view of Manhattan glistening like the Emerald City or an enchanted isle. Somehow transformed, full of hope and determined, fed by Mac's final lyric "you can lie down, or you can get up and play." We had worked our way through the delight and darkness of America's shadowy past in an attempt to find a commonality on which to build new community. After all, recent years in the United States had seen the election of the first black president, nation-wide marriage equality and the rise of grassroots movements from Occupy Wall Street to Black Lives Matter. But perhaps A 24Decade History of Popular Music, no matter how magical, was another example of isolationism, of constructing an event that built community through hope, but inside of a transparent bubble of which we were unaware. In the early morning hours of November 9, 2016, exactly one month after the concert had ended, the spirit l'avenir resurrected itself as a dark horse with the election of Donald J. Trump as the $45^{\text {th }}$ President of the United States. With a heavy heart I watched my social media feeds change from the afterglow of Mac's performance (still going strong four weeks later) to expressions of disbelief, sadness and fear. Although the structure of what we had created with Mac seemed to crumble in that moment, it also exposed what the concert was really aboutthe necessity to stay present and hold steadfast as the gears of history continue to turn.

Amidst the rubble Mac is changing into his next ensemble, I imagine a feathered phoenix resplendent in sequins, Ariel-like and more terrifying and brilliant than one can even imagine. Judy refuses to lie down in defeat or apathy and is ready to get up, to take action in play. If Derrida was correct about looping time as Mac so poignantly demonstrated, only in the future can the events of today start to make sense. Hopefully, then, as we shatter our glass domes of insulating protection, in a rainstorm of crystal shards, can we spur a sea change. 